\title{
'An Origin for Political Culture': Laws 3 as Political Thought and Intellectual History
}

\author{
Carol Atack \\ Newnham College, University of Cambridge, Cambridge, UK \\ cwa24@cam.ac.uk
}

\begin{abstract}
Plato's survey in Laws book 3 of the development of human society from its earliest stages to the complex institutions of democratic Athens and monarchical Persia operates both as a conjectural history of human life and as a critical engagement with Greek political thought. The examples Plato uses to illustrate the stages of his stadial account, such as the society of the Cyclops and the myths of Spartan prehistory, are those used by other political theorists and philosophers, in some cases also drawing on the presence of the same stories in classical Greek epic and tragedy. By incorporating his critique into a timeline Plato is able to suggest that some approaches are limited in scope to specific social conditions, whereas his Athenian Stranger presents his analysis from an external and superior viewpoint, looking down on human society from above.
\end{abstract}

\section{Keywords}

Plato - conjectural history - constitutions - development - stadial theory

There is a developing tradition of reading Plato as engaged in a systematic critique of Greek political culture and theoretical responses to it, often using the Republic as a starting point. ${ }^{1}$ This paper aims to show that Laws 3, Plato's account of the development of human society and the political structures it incorporates, functions as a critical analysis of other political commentators

1 S. Brill, 'Plato's Critical Theory', Epoché: A Journal for the History of Philosophy 17 (2013), pp. 233-48; J. Thakkar, Plato as Critical Theorist (Cambridge, MA: Harvard University Press, 2018). 
embedded within a linear narrative of a systematic conjectural framework that itself offers a critique of the use of mythical and historical exemplars in political theorising. The Athenian Stranger sets out a series of stages, each illustrated with familiar examples already in use in other political texts. He positions himself in an external, objective super-position resembling that of the god in the Statesman's Age of Zeus (Plt. 272e) or the philosopher in the Theaetetus digression (Tht. 173e-174a). Eventually Plato has the Athenian Stranger replace this framework with a different model, which looks outside human history, but he first uses it to identify limitations in the theorising of his rivals who are committed to working within it. ${ }^{2}$ The Athenian Stranger's standpoint is echoed by the dramatic setting of the dialogue itself, with its absence of clear markers for dramatic date, distance from the Athens, Sparta and Persia that are the focus of the political analysis of Laws 3, and the absence of historical persons as participants in the dialogue.

Laws 3 develops a variety of possible outcomes of the long developmental process, negotiating between the ideal and the practical, and finally positioning democracy and monarchy as outliers among the possible constitutional forms. Previous readers have focused on this structure (Schöpsdau), the playful account of early history (Weil), and the iterative engagement with Plato's own earlier thought (Schofield, Rowe). ${ }^{3}$ Andrea Nightingale noted its argumentative function, characterising it as opposed to book 1o's cosmology, while Cynthia Farrar detailed its engagement with Thucydidean historiography. ${ }^{4}$ Others have explored the way that it opposes the historical model, and historical exemplars, to a more cosmological perspective. ${ }^{5}$

Reading the text as one operating within a developing canon of political theorising suggests that a significant feature of the Laws 3 development story

2 The extent to which the opinions expressed by the Athenian Stranger can be identified with Plato's own opinions is the subject of debate.

3 R. Weil, L'Archéologie' de Platon (Paris: C. Klincksieck, 1959); M. Schofield, 'Religion and Philosophy in the Laws', in S. Scolnicov and L. Brisson (eds), Plato's Laws: From Theory into Practice (Sankt Augustin: Academia, 2003), pp. 1-13; C. J. Rowe, 'The Relationship of the Laws to Other Dialogues: A Proposal', in C. Bobonich (ed.), Plato's Laws: A Critical Guide (Cambridge: Cambridge University Press, 2010), pp. 29-50; K. Schöpsdau, Nomoi = Gesetze (Göttingen: Vandenhoeck \& Ruprecht, 1994).

4 A. W. Nightingale, 'Historiography and Cosmology in Plato's Laws', AncPhil 19 (1999), pp. 299326; C. Farrar, 'Putting History in Its Place: Plato, Thucydides and the Athenian Politeia', in V. Harte and M. S. Lane (eds), Politeia in Greek and Roman Philosophy (Cambridge: Cambridge University Press, 2013), pp. 32-56.

5 S. Broadie, Nature and Divinity in Plato's Timaeus (Cambridge: Cambridge University Press, 2012); D. J. O'Meara, Cosmology and Politics in Plato's Later Works (Cambridge: Cambridge University Press, 2017), pp. 122-25. 
is its provision of spaces within which Plato can engage with other political thinkers and criticise methodologies reliant on examples from the past. By placing pseudo-historical exemplars familiar from the theorising of his immediate contemporaries and predecessors within this story, Plato engages in dialogue not just with the mythical and epic traditions of the past but also the debates of the present, with contemporaries such as Isocrates and Xenophon who frequently use such examples; here they go unnamed, as is Plato's frequent practice when criticising rival educators. ${ }^{6}$ Placing this engagement within the developmental framework that the Athenian Stranger goes on to reject (Laws 4.712b-713b), he denies other theorists the status of his own superior perspective. Plato is able to set two methodologies in opposition, and although the Athenian Stranger should not be assumed to be his mouthpiece, the similarity between the latter's opposed models and those contained in Plato's other late dialogues suggests that Plato is using him to present a model of which he himself approves.

\section{Developmental Frameworks for Political Thought}

Plato's account draws on a well-established tradition of Greek political writing. Schematic models of the past are common in Greek literature; they incorporate varied attitudes to change and openness to the possibility of progress. Herodotus incorporates models of change within a cyclical pattern of the life of cities, in which periods of deterioration match periods of improvement (Herodotus 1.5.4). Aristotle explains why a longue-durée developmental model is important; going back to the beginning and tracing development is a sound methodology for understanding the complete whole. He notes that 'In this, as in other fields, we shall be able to study our subject best if we begin at the beginning and consider things in the process of their growth' (Politics 1.2, 1252a24-26, translation Barker/Stalley). ${ }^{7}$ As Plato's larger picture shows, developmental models operate as segments of cyclical models and can be subsumed within them.

In Laws 3 Plato extends this picture to set human endeavour within a larger framework of cosmic cycles which wreak periodic destruction on it. Human

6 On Plato's methods for anonymous allusion, using the example of allusion to Gorgias in Republic book 3, see R. Wardy, 'The Platonic manufacture of ideology, or how to assemble awkward truth and wholesome falsehood', in Harte and Lane (eds), Politeia, pp. 119-38, at pp. 128-29, n. 18.

7 R. F. Stalley (ed), Aristotle: Politics, trans. E. S. Barker (Oxford: Oxford University Press, 1995). 
society does not survive from one era to another (cf. Plt. 273ab); the Statesman myth offers the grandest take on cyclicality in the Platonic corpus. ${ }^{8}$ Plato also revisits the image of the divine shepherd nurturing the human flock (Plt. 271d6-7), an image resurgent in fourth-century Greek political thought as an analogy for the rule of a virtuous and excellent leader (Republic 1.343b-345e; Xenophon, Cyropaedia 8.2.14). ${ }^{9}$ Models of political rule that position the ruler as qualitatively distinct from the ruled risk generating a hierarchical political ontology, and fail to produce a political regime of humans collaborating for mutual benefit, but deliver a golden age in which human endeavour is minimised by divine assistance, a problem that dogs fourth-century Greek political thought and of which Plato is clearly aware. ${ }^{10}$

Aristotle's conjectural history of the polis sees elements of early stages of the developmental process as parts persisting embedded in the developed whole. The family, the earliest form of association, is a building block of the polis, the final form of association (Politics 1.2). Plato has already noted this structure (Laws 1.626-7). But he queries the relevance of the early stages of development to contemporary politics: is it possible that humans living in primitive associations could develop virtue to the same extent that those in advanced associations do? Might exemplars from ancient times simply be irrelevant to the life of the developed polis because of their simplicity and lack of scale (as he suggests at 3.678b1-3)? For Plato, development changes the quality of all elements of a society, including the characters of its citizens, rather than aggregating persistent simple elements into larger groupings.

Thucydides' archaeology (1.2-19) offers one model for the early stages of human development, but is focused on the development of the polis and relationships between cities, a narrow section of the whole developmental story (1.2.1-2). ${ }^{11}$ As Cynthia Farrar saw, Thucydidean themes recur throughout Laws 3; however, foregrounding Thucydides as a referent side-lines Plato's engagement with the historians and thinkers who were his own contemporaries. ${ }^{12}$ Fourthcentury developments in historiography should not be ignored. Didactic history with its emphasis on the paradeigma, and exemplary narrative, and seen even in texts that purport to offer continuous narrative history such as

8 Weil, Archéologie, pp. 13-5.

9 R. Brock, Greek Political Imagery from Homer to Aristotle (London: Bloomsbury, 2013), pp. $43-52$.

10 Cf. Aristotle's exploration of total kingship (pambasileia) in Politics 3. On the ontology implicit in kingship models, see M. Sahlins and D. Graeber, On Kings (Chicago: HAU Press, 2017), pp. 1-14.

11 Weil, Archéologie, pp. 63-64.

12 Farrar, 'Putting History in Its Place', pp. 34-35. 
Xenophon's Hellenica, is one comparator. ${ }^{13}$ Laws 3 , with its repeating examples punctuating its analysis, fits this pattern. Histories which combined the stories of many cities were another emerging strand of historiography. ${ }^{14}$ The loss of many of these texts makes it hard to interpret resonances between them and the Laws; fragments of Ephorus' histories, probably post-dating Plato, suggest some shared elements, including a reworking of Cretan myth distinct from the usual Athenian perspective. ${ }^{15}$

Plato's conjectural model in the Laws surveys the development of human community in its broadest sense, as the presence of non-Greek and non-polis examples - Troy, Egypt, Persia - suggests. ${ }^{16}$ Even Sparta, in its early history, can be seen as an ethnos state rather than a politeia (683a7-8). This model has three early stages: the life of the scattered survivors of catastrophe (677a1-68oe5), the development of agriculture (680e6-681d6), and the foundation of cities $\left(681 \mathrm{~d} 7-683^{\mathrm{c}} 7\right)$, followed by a fourth stage, the perfection of the politeia as exemplified by Sparta (683c-686c), which sets up the final part of the book with its comparison of constitutions. ${ }^{17}$

Such large-scale models of 'conjectural history' were a notable feature of the historiography and social thought of the Scottish Enlightenment, often referred to as stadial theory, explaining change over time not from empirical historical evidence but from theorised reconstruction. Examples include Adam Ferguson's 1767 essay on the history of civil society, and Adam Smith's lectures from the previous year, which set out the model: ${ }^{8}$

13 F. S. Pownall, Lessons from the Past: The Moral Use of History in Fourth-Century Prose (Ann Arbor: University of Michigan Press, 2004) shows how didactic exemplary historiography worked.

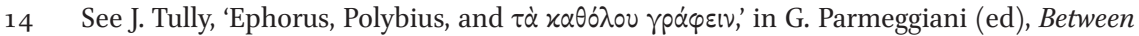
Thucydides and Polybius: The Golden Age of Greek Historiography (Cambridge: Harvard University Press, 2014), 153-96.

15 G. R. Morrow, Plato's Cretan City: A Historical Interpretation of the Laws (Princeton: Princeton University Press, 196o), pp. 23-25; Morrow sees Plato as the 'coryphaeus of the pro-Cretan group'.

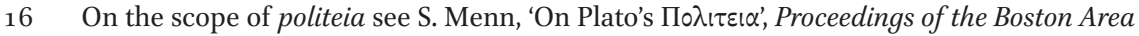
Colloquium in Ancient Philosophy 21 (2006), pp. 1-55, J. Bordes, Politeia dans la Pensée grecque jusquà Aristote (Paris: Les Belles Lettres, 1982).

17 Schöpsdau, Nomoi, pp. 354-56. I plan to treat the later sections of Laws 3 narrative, and the contrast between Athens, Persia and Sparta, elsewhere.

18 R. L. Meek, D. D. Raphael, and P. Stein (eds), The Glasgow Edition of the Works and Correspondence of Adam Smith, Vol. 5: Lectures on Jurisprudence (Oxford: Oxford University Press, 1978), report of 1766, pp. 149-50; A. Ferguson, An Essay on the History of Civil Society, ed. F. Oz-Salzberger (Cambridge: Cambridge University Press, 1995). Sparta is a key example for Ferguson, at pp. 151-55, 85-88. 
The four stages of society are hunting, pasturage, farming, and commerce. If a number of persons were shipwrecked on a desert island their first sustenance would be from the fruits which the soil naturally produced, and the wild beasts which they could kill. As these could not at all times be sufficient, they come at last to tame some of the wild-beasts that they might always have them at hand. In process of time even these would not be sufficient, and as they saw the earth naturally produce considerable quantities of vegetables of its own accord, they would think of cultivating it so that it might produce more of them.

Plato's model resembles this conjectural history (although it is markedly more pessimistic). It also contrasts with Thucydidean historiography, which was held as an antecedent by proponents of the Rankean scientific historiography which replaced conjectural histories. ${ }^{19}$ However, reading the first part of Laws 3 with this methodological distinction in mind is illuminating, and suggests that the difference goes beyond providing a structure to incorporate the distant past into a continuous historical narrative. ${ }^{20}$

Laws 3 follows the Timaeus/Critias in drawing back from the Statesman's grandiose schema; rather than full-scale cosmic reversal, human culture is destroyed by a more localised geographic disaster, typically identified as a flood or cataclysm. It is important for this more modest model that Egypt, absent from the Laws 3 narrative although already invoked at 2.656d-657a, is exempt from destruction. ${ }^{21}$ Egypt's long-term stability and its rulers' conscious rejection of change contrasts with the swift decline Plato goes on to describes in Athens and Persia, as the extremes of both monarchy and democracy prove to be unstable. Its music (7.799ab) contrasts with the new music of democratic Athens, which the Athenian Stranger later criticises (3.700a-701b). The setting of the Laws itself also lacks temporal markers; the only temporal structure is that generated by the Athenian Stranger. ${ }^{22}$ This contrasts with dialogues set in Athens, where temporal markers in the dramatic setting alert readers to events which might render the dialogue's discussions more pointed in their

19 D. Allan, 'Scottish Historical Writing of the Enlightenment', in J. Rabasa et al. (eds), The Oxford History of Historical Writing: Volume 3: 1400-1800 (Oxford: Oxford University Press, 2012), pp. 497-517.

20 Cf. Farrar, 'Putting History in Its Place', p. 36.

21 See L. Brisson, 'L'Égypte De Platon', Études Philosophiques 153 (1987), pp. 153-68.

22 This temporal openness led Catherine Zuckert, for example, to argue for the Laws being set in a time prior to that of Plato and Socrates, but contemporary with the earlier Presocratics (C. H. Zuckert, 'Plato's Laws: Postlude or Prelude to Socratic Political Philosophy?', Journal of Politics 66 (2004), pp. 374-95). 
connections to historical context, and occasionally conflict. ${ }^{23}$ The placement of examples and ideas used by other thinkers in specific points in his narrative suggests that their scope is more limited than the overview available to the Athenian Stranger.

The opening of book 3 serves as a methodological and programmatic statement, recalling those of Herodotus and Thucydides, and setting this account in dialogue with the existing traditions of political historiography. ${ }^{24}$ It also reprises the beginning of the first book: 'AS: Is it a god, my friends, who in your view should take credit ( $\alpha i \tau i \alpha \nu)$ for your legal arrangements ( $\nu o ́ \mu \omega \nu)$ ? Or some human?' (Laws 1.624a1-2, translation Griffith/Schofield)

Many commentators have noted how the opening of the third book echoes and reconfigures this opening question, linking its inquiry to it. ${ }^{25} \mathrm{Here}$, the Athenian Stranger identifies the next topic of discussion as the origin of politeia, rather than the laws mentioned previously:

AS: ... Now, the origin of a politeia ( $\left.\pi 0 \lambda \imath \tau \varepsilon i \alpha \varsigma \delta \dot{\varepsilon} \alpha \dot{p} x \eta^{\prime} \nu\right)$ - what are we to say about that? Isn't there a place from where one might look upon ( $\varkappa \alpha \tau i-$ $\delta \circ 1)$ it in the easiest and finest way?

Cleinias: From where?

AS: From where the development of cities as they move towards virtue or vice, in any particular case, can be seen $(\theta \varepsilon \alpha \tau \varepsilon \dot{o v})$.

Laws 3.676a1-6

This change of topic is less clear than it might be; both archē and politeia are polyvalent. Archē suggests both 'elementary form' (as England has it) and

23 Most notably in Plato's treatment of thinkers he identifies as sophists, and the ideas he associates with them; see C. Atack, 'Plato's Queer Time: dialogic moments in the life and death of Socrates', Classical Receptions Journal 12 (2020), pp. 10-31.

24 Weil, Archéologie, pp. 40-41 identifies this as a particularly dialogic passage.

25 J. Sallis, 'On Beginning after the Beginning', in G. Recco and E. Sanday (eds), Plato's Laws: Force and Truth in Politics (Bloomington: Indiana University Press, 2013), pp. 75-85; M. J. Lutz, Divine Law and Political Philosophy in Plato's Laws (DeKalb: Northern Illinois University Press, 2012), pp. 76-77. 
'origin' (as Schofield and Griffith, and Schöpsdau suggest). ${ }^{26}$ This ambivalence places the inquiry between historiography and philosophy, in each of which one sense might predominate. Given the emphasis on virtue and vice, this looks like a more broadly normative project, similar to the practices of didactic historiography. But the external perspective required for this process is also significant; we must look down on events from outside. This appears to challenge the partisan viewpoint of historiographers. The usefulness of this external perspective is a concern already raised in the Republic: there, the question is whether human life will be of interest to a high-minded thinker focused on 'all time and all being' (Republic 4.486a). In the Laws, Plato uses aspects of the grand framework to organise a smaller-scale inquiry into the origins of the politeia, but then returns to the larger picture as he sets aside the developmental view, suggesting that historiography and political case studies can only offer a limited analysis. However, the critique of political writing in Laws 3 also covers the use of exemplarity in genres beyond historiography.

Without the facility for systematisation, the amount of material to be surveyed, boundless in its immensity, renders autopsy on a human scale impossible, and comprehension difficult:

AS: That of a long or infinite period ( $\dot{\alpha} \pi \varepsilon i p i \alpha \varsigma)$ of time, I would say together with the changes occurring in it.

Cleinias: Explain.

AS: Well, take cities and people living together under some kind of political system. How long has that been going on for? Is that something you could ever form any conception of, do you reckon?

Cleinias: Well, it certainly wouldn't be easy, that's for sure.

AS: But you do know that it would be an inconceivably vast ( $\ddot{\alpha} \pi \lambda \varepsilon \tau \circ \nu \tau$ xai $\alpha \mu \eta \dot{\chi} \chi \alpha \nu \circ v)$ expanse of time.

Laws 3.676a7-b7

The Athenian Stranger's formulation here moves the inquiry from the language of historiography to that of philosophical speculation, on the infinite

26 E. B. England, The Laws of Plato (Manchester: University Press, 1921), Vol. 1, p. 343; Schöpsdau, Nomoi, p. 341; M. Schofield (ed.), Plato: The Laws, trans. T. Griffith (Cambridge, 2016), p. 100. 
and unmeasurable, marked by the use of alpha privatives. He explains that the sheer number of cities and their mutability in size and quality complicate any project of systematisation, but that it might be possible to find an underlying pattern:

AS: During that time, don't we find, thousands upon thousands of cities have existed, and by the same reckoning, as many have been destroyed. And as for each one's social and political arrangements at various times, haven't they been of every possible kind, as cities have at one time grown larger, at another smaller, at one time worse, and at another better?

Cleinias: Unquestionably.

AS: Let's see if we can find the reason for this kind of change. It may perhaps show us the first origin $\left(\pi \rho \omega \dot{\tau} \tau \nu\right.$... $\left.\gamma^{\varepsilon} v \varepsilon \sigma \tau\right)$, and later development ( $\mu \varepsilon \tau \dot{\alpha} \beta \alpha \sigma \nu)$, of social and political systems.

Laws 3.676b9-c8

An analysis based on empirical evidence might well be impossible owing to the diversity and quantity of data involved, unless a higher-order investigation of the processes of change can explain the way in which societies develop. In suggesting that they search for an aitia, the Athenian Stranger appears to yoke the enterprise to a Thucydidean perspective, but whereas Thucydides seeks the causes of a specific event, the Peloponnesian War (Thuc. 1.23.5), the Athenian Stranger seeks the causes of more abstract processes of societal development and change. In accessing these, the possibility of a better understanding of the history of the uncountable poleis might emerge. From the original foundation, it might seem as if all the present politeiai and the associated skills emerge; the Athenian Stranger leads Cleinias through a series of questions (3.677e6-678b8) which set out the plan without endorsing it. The reason for this reticence will become clear when the Stranger rejects the whole project in the next book, in favour of a different model.

With this second introduction, Plato differentiates the endeavour of Laws 3 from that of ancient historiography. Historians aim to explain specific events, the subjects of their monographs, but the Athenian Stranger is interested in processes rather than events. However, a secondary goal emerges, of demonstrating how other political thinkers' use of specific examples, and perhaps even specific types of example, such as heroic foundation story, narrow their scope and fail to attain the lofty perspective that is the Athenian Stranger's ideal. Throughout this survey, Plato draws on other thinkers' assessments of 
human arrangements and links them to particular stages within the model, often because they themselves have identified them as exemplars. In this respect, Laws 3 displays a similar use of exemplarity to early modern political writing, as identified by Joshua Foa Dienstag; the examples on which Plato draws are mediated through the texts of other writers rather than arising from direct historical analysis or autopsy. ${ }^{27}$ Dienstag identifies such an approach as characteristic of political theorising; acknowledging the literary basis of exemplarity in Laws 3 reveals its theoretical and critical purpose.

\section{3}

\section{Antisthenes and the Homeric Cyclopes}

Plato's second stage identifies the beginnings of community in small-scale family-based societies, as survivors descend from the hilltops, which enables him to join an existing theoretical discussion about the early stages of human society, which uses Homer as its source material, and exemplifies the patterns identified by Dienstag. Understanding the existing use of the Cyclopes as exemplars within Greek literary culture and as an exemplar in political theorising is a prerequisite for interpreting this section of the work; treating Plato's reference as simply an engagement with Homeric sources is insufficient, although comparison with other Platonic invocations of Homer (in the Protagoras and Republic, for example) may also be instructive. ${ }^{28}$ The model of early society presented by the Athenian Stranger is more peaceful than Thucydides'; during this period, 'civil conflict and war alike were ended' (678e5-6). Its invocation of the Cyclopes suggests an engagement with the Socratic thinker Antisthenes, who also used them as an exemplar within an existing debate on primitive society.

Antisthenes' political thought survives in scant fragments, often transmitted indirectly. But some context for the fragments is provided by other Socratic writers, notably Xenophon, from he can be seen to have engaged with important themes of post-Socratic political thought, such as the idea of a 'royal art',

27 J. F. Dienstag, 'The Example of History and the History of Examples in Political Theory', New Literary History 48 (2017), pp. 483-502.

28 Cf. S. Benardete, Plato's Laws: The Discovery of Being (Chicago: University of Chicago Press, 200o), pp. 97-10o. On Plato's use of Homer see H. Segvic, 'Homer in Plato's Protagoras', Classical Philology 101 (2006), 247-62. 
basilike technē. ${ }^{29}$ In one surviving fragment, Antisthenes appears to treat the Homeric Cyclopes as a golden-age society in which questions of justice arise: ${ }^{30}$

But Antisthenes says that only Polyphemus was unjust ( $\alpha \dot{\delta}(x \circ v)$; for he was genuinely disdainful of Zeus; and so the rest were just ( $\delta i x \alpha 101)$, and for this reason the land gave everything to them spontaneously, and not working it was a just deed.

Antisthenes Fr. 189A=Porphyr. schol. ad Od. 9.106

The land gave forth produce spontaneously so no labour was required. Commentators have suggested that Antisthenes' primary concern in these fragments was a linguistic concern with the language of justice, demonstrated by the difference between Polyphemus and the others. ${ }^{31}$ Lucia Prauscello has shown how Plato engages with this existing debate, focused on the role of nomos in society. ${ }^{32}$ But given the importance of Homer throughout the work of Antisthenes, it may be fair to assume that there is a political-theoretical link here, and that there is a political theoretical need to develop conceptual precision. ${ }^{33}$ But if his analysis is appropriate to an incomplete stage of human development, it may be less useful in the complete stage, the polis.

Homer sets the Cyclopes on an island, with golden-age features that place it outside the framework of the human past (Od.9.105-115), although Odysseus claims to have encountered it in the course of his extended return from Troy. Plato, however, repositions the Cyclopean society into the early post-flood age:

I think I'm right in saying that the name everybody gives the political system of those times is autocracy, which is still to be found to this day in many parts of Greece and among the barbarians. It is what Homer is talking about, I imagine, when he describes the households of the Cyclopes. He says of them:

29 L.A. Dorion, L'Autre Socrate: Études sur les Écrits socratiques de Xénophon (Paris: Les Belles Lettres, 2013), pp. 147-69; C. Atack, The Discourse of Kingship in Classical Greece (London: Routledge, 2020), Ch. 4.

30 S. H. Prince, Antisthenes of Athens: Texts, Translations, and Commentary (Ann Arbor: University of Michigan Press, 2015), pp. 584-697 catalogues Antisthenes' wide-ranging use of Homer.

31 A. Brancacci, Oikeios Logos: La Filosofia del Linguaggio di Antistene (Napoli: Bibliopolis, 1990), pp. 66-69, cf. Prince, Antisthenes, pp. 631-54.

32 L. Prauscello, 'Plato Laws 3.68ob-c: Antisthenes, the Cyclopes and Homeric Exegesis', JHS 137 (2017), pp. 8-23.

33 Schofield (ed), Laws, p. 105 n. 8. 
They hold no meetings to deliberate,

Obey no law. In hollow caves they dwell,

High in the mountain peaks, and each provides

Himself in his own law for his wives and children,

And cares not for his fellows.

Laws 3.68ob1-8 including HOMER Odyssey 9.112-15

The lack of competition for resources among the scattered survivors of the flood may resemble a golden age, in that agriculture is not necessary for survival, or is impossible given the state of the land and the restriction of human life to the peaks of hills and mountains. Reading Plato's text as a critique of Antisthenes' primitivism suggests that the latter has mis-recognised the status of such societies, in treating them as part of the golden age; even if the mythical Cyclopean society belongs to the golden age, human societies with the same features have a different cause, the slow recovery from cataclysm.

In attaching Cyclopean analogies to an early stage of human pre-history, Plato makes a further point, that Antisthenes' concern about the distinction between the unjust Polyphemus and the just Cyclopes is misplaced. The possibility of any meaningful form of justice being present in this stage of the developmental model, where no true community has really developed, is minimal. By using Homeric myth as a model for a just society, Antisthenes has erred. Plato, in pinning Antisthenes' thought on justice to this pre-society, attaches it to the remote past. This family-based pre-society depends on the authority of the eldest member (68ode), and the gathering of the family like birds in a 'single flock' (68oe1-2); this is the form of rule that the Athenian Stranger

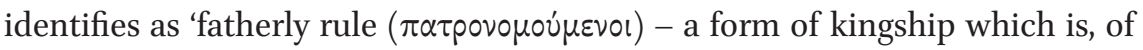

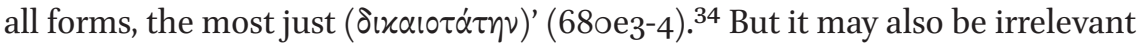
to political life in more complex societies; rule by father and mother is the first claim to authority of those listed in the Athenian Stranger's second, more abstract account of authority (69oe3-4). Such authority may be subsumed into the larger structures of the polis (as it is in Aristotle's developmental account, Pol.1.2, 1252b27-1253a1), but it may also be replaced.

Poets provide evidence for the next two stages of development, the early descent from the hilltops to form larger groupings and villages (68oe-681b), and the subsequent descent to the plains and development of major settlements (681e-682d), of which Troy is the exemplar. The foundation of Troy represents a growing confidence in human society as well as the forgetting of

34 The account of seven forms of authority, which separates this prehistory from the account of the Persian Wars (3.69oal-c9) provides a further schematic framework. 
the destructive flood; here the main sources with which the Athenian Stranger engages are poetic, both epic and tragic. Poets, the Athenian Stranger asserts, are well-positioned to analyse these stories: 'For since the poetic class really is divine and inspired when it sings songs of praise, with the help of Graces and Muses it grasps on each occasion the many things that come into being in accordance with the truth' (682a3-5). This offers a distinctive critique of poets' historical analysis; their success derives from their divine inspiration not their own efforts, and although one might collect the many particular events they have gained a true picture of, they remain separate..$^{35}$

Poetic accounts of past societies may therefore join, rather contrast with, the limits of particularity found with historiographical accounts. The Athenian Stranger's approach appears to address this by building a coherent and unified narrative. Plato will address this in considering how to construct the preludes with which the Athenian Stranger believes that the citizens can be persuaded to obey the law; the Laws is itself the 'truest tragedy' $(7.817 \mathrm{~b} 3-5) \cdot{ }^{36}$ But the transition point offered by the Trojan War is itself a precise time, and the war's ten-year duration is emphasised (682d1-e2).

\section{4 \\ Athens, Isocrates and the Messenian League}

Following the establishment of cities comes the Trojan War, leading to the fourth stage in the Athenian Stranger's process (683a7-8), itself another attempted beginning (oîv $\dot{\xi} \xi \hat{\alpha} p X \hat{\eta} \varsigma, 683 \mathrm{~b} 5$ ), which explores political relationships within and between cities, starting with the return of the Heraclids to the Peloponnese and the foundation of Sparta. The return of the Trojan heroes was far from simple - here, with 'death, slaughter ( $\sigma \varphi \alpha \gamma \alpha$ s) and exile on a grand scale $(\pi \alpha \mu \pi \dot{\partial} \lambda \alpha \varsigma)$ ' (682e1-2), Plato alludes to poetic accounts such as Aeschylus' Oresteia. This section of the Athenian Stranger's narrative engages with episodes critical to the historiography and political thought of Plato's contemporaries, conventionally used to date the start of history, at the end of the heroic age and of the direct intervention of gods in human affairs. ${ }^{37}$ Here the Athenian Stranger's interest is in the developed practices and interrela-

35 Cf. Aristotle's comparison of poetry and historiography in his Poetics (1.9, 1451a38-1451b11).

36 A. Laks, 'Plato's “Truest Tragedy”: Laws Book 7, 817a-d', in C. Bobonich (ed.), Plato's Laws, pp. 217-31.

37 Diodorus Siculus 16.76.5 = Ephoros BNJ 70 T10; see Nino Luraghi, 'Ephorus in Context,' in G. Parmeggiani (ed.), Between Thucydides and Polybius, pp. 133-52, for a critical assessment of whether these events represent an epochal divide in Greek historiography. 
tionships of cities, exemplified by the establishment of the Dorian League of the states of Sparta, Messene, and Argos.

The Stranger interrogates the Athenian Spartan mirage as much as the Spartans' own stories, noting that his version differs from the familiar Spartan myths (682e4-6). ${ }^{38}$ It was used in Euripides' Cresphontes (so this section retains the link to tragedy), and later by Isocrates in his speech Archidamus. The context of the Peloponnesian War, and related interest in collapsing defensive leagues, made the myth highly relevant to Athenians in the late fifth century все. ${ }^{39}$ But the fourth century saw a change in perceptions of Sparta after the collapse of its post-war hegemony, the agreement of the King's Peace in 386 все, and the rise of other powers within the Greek world. ${ }^{40}$

Isocrates uses this story to point to Sparta's loss of power, and dependence on Athens in the mythical tradition, but his Archidamus admits that

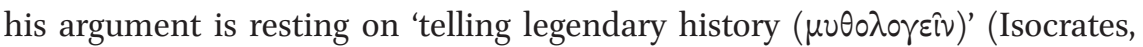
Archidamus 24). Isocrates uses this speech, supposedly given by the young Spartan prince, to draws parallels between the mythical help Sparta received from Athens in aiding the return of the Heraclids, and ancient Sparta's support to the Messenians, giving the mutual support pledged by the three kingdoms of the Dorian League. ${ }^{41}$ His allusions to this history are part of his continuing critical engagement with Athenian Laconophilia, and his extensive use of civic foundation myths to support his arguments for Athens-led Panhellenic wars on Persia.

Plato's use of the story of the Dorian League positions the Laws 3 narrative within this critical tradition, but whereas Isocrates' point is to reaffirm Athenian superiority over Sparta, Plato finds a more positive story to abstract from this highly patterned mythical narrative. His Athenian Stranger highlights the relationship between the kings and the demos, and turns the formation of the Dorian League into an early instance of the development of a mixed constitution, a theme that will recur later in the book:

38 Cf. Schofield (ed), Laws, p. 109 n. 15, who notes that Plato reverts to a more standard account at 685 .

39 A. Harder, Euripides' Kresphontes and Archelaos: Introduction, Text, and Commentary (Leiden: Brill, 1985), pp. 7-12.

40 P. Cartledge, Sparta and Lakonia: A Regional History, 1300-362 BC (London: Routledge, 2002), pp. 228-6o details Sparta's fourth-century decline.

41 T. G. M. Blank, Logos Und Praxis: Sparta Als Politisches Exemplum in Den Schriften Des Isokrates (Berlin: De Gruyter, 2014), pp. 287-378; C. Atack, 'Imagined Superpowers: Isocrates' Opposition of Athens and Sparta', in P. Cartledge and A. Powell (eds), The Greek Superpower: Sparta in the Self-Definitions of Athenians (Swansea: Classical Press of Wales, 2018), pp. 157-84, at pp. 167-72. 
What happened was this: each of the three royal houses, and each of the three cities subject to them, swore oaths to one another, in accordance with the laws that they had put in place, which applied to ruler and ruled alike. The kings swore that they would not make their rule harsher with the passage of time and the generations; the people swore that in return, if the rulers kept their word, they would neither themselves overthrow the kingship, nor tolerate any attempt by anyone else to do so.

Laws 3.684a2-b1

The history of the league has been rendered rather abstract to produce a set of political relationships that counterbalance each other, as the elements of the mixed constitution should. This version of Sparta is distinct from that of Xenophon's Constitution of the Lacedaimonians, which positions Lycurgus as the lawgiver and sole founder of the politeia (Xenophon, Lac. Pol. 1.2, 5-8). When Plato returns to Spartan history in the second part of Laws 3 (691d-693a) the Xenophontic version of Sparta returns into view, in a further critical engagement with Athenian Laconophilia.

\section{$5 \quad$ Plato's Rejection of Developmental Models}

Plato's developmental account of human communities of increasing complexity and size provides a framework into which he can place the analysis of previous thinkers as a means of criticising their method. In constructing his account from examples used by other writers, he implies criticism of their analyses, that their exampla offer snapshots of unique instances rather than holistic accounts of the complete story from beginning to end. Their utility may also be restricted to the narrow context to which they apply; Antisthenes' account of justice, if it is specific to Cyclopean society, might be useless for the analysis of Athens.

These accounts lack the overview from an ideal external vantage point which the Athenian Stranger has claimed for himself. In constructing his Laws 3 model on a larger scale, Plato acknowledges a trend in fourth-century Greek literature, the larger-scale, synoptic account, that shows the forces of change at work over a long period, but with the intention, made explicit in book 4. These could be focused on a specific topic, such as the history of a single polis, as the Aristotelian constitutions with their accounts of change within a single politeia do, or connect such stories into a larger narrative, as Ephorus' universal history did. But the opposition between the Laws 3 narrative and the 
Age of Kronos myth in Laws 4 suggests that Plato wishes to suggest that even larger-scale historical narratives are of limited analytical value.

Questions of scale, often linked to distinctive epistemic statuses, recur throughout Plato's work. The Republic's city-soul analogy, for example, suggests that it might be easier to discern justice in the larger-scale entity, and embarks on another developmental account to do so (Rep. 2.368d1-7); watching the development of the city might enable one to spot when justice comes into being: 'If we could watch the city coming into being in theory wouldn't we also see its justice coming to be, and its injustice as well?' (Republic 2.369a)

This model enables Plato to chart a relationship between the timeless quality of justice and the changeable nature of the city, which he pursues through a developmental model that is in some ways a precursor to that of the Laws. The Republic's account of the decline of constitutions also suggests elements of the later sections of Laws 3, in which the Athenian Stranger explores the decline of monarchy and democracy through episodes from Persian and Athenian history.

Leaving his story of historical constitutions at a point where change is for the worse, the Athenian Stranger instead seeks for an alternative model. He finds one outside the scope of his temporal survey, in the story of Kronos and the golden age in which, as in the Statesman myth, humans were pastured in herds by divine beings. This is briefly retold at $4.713 \mathrm{c} 2-714 \mathrm{~b} 1$. We are returned to the divine rule of the golden age, which is revealed to be the source of the best model for cities in the present:

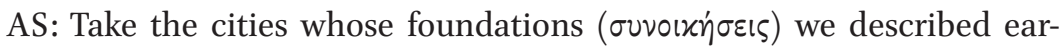
lier - well, even before those, long before, in the time of Kronos, there

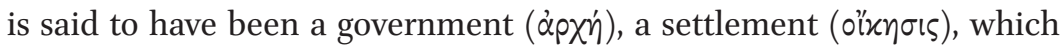
was blessed by the gods and which serves as a model $\left(\mu \mu \eta^{\prime} \mu \alpha\right)$ for all the best-run cities nowadays.

Laws 4.713a9-b4

So, at its conclusion, the entire exercise of the Laws 3 developmental account is set aside in favour of a myth of divine governance; the project for devising a constitution, which occupies the remainder of the Laws' twelve books, is to deliver a set of rules which can bring this model to life. In the end, the Athenian Stranger's pseudo-historical account has enabled critiques of a range of earlier thinkers, as well as a more general critique of historical exemplarity as a method. It must be set aside before real progress can be made in devising a new constitution capable of delivering an approximation to the ideal. 
The developmental narrative of the opening section of Laws 3 provides an argumentative response to historiographical and mythical accounts of the development of society in use by Plato's predecessors and contemporaries. Some of its complexities and inconsistencies, and its selection of events and details, can best be understood as Plato's specific critical engagement with the accounts of rival thinkers, as a structure for an intellectual history rather than a history of events. This reading also explains why Plato undertakes this lengthy and detailed exercise, but is able to set it aside at the start of book 4 in favour of the construction of a politeia within his own timeless framework. For Plato, a historical developmental account of society can never be sufficient, but it can provide a useful framework for ordering his critique of the social and political thought of his contemporaries and rivals. ${ }^{42}$

42 I would like to thank the organisers of the Bergen workshop, and the workshop participants, the editors and anonymous reviewer for their helpful comments on this paper, which emerged from work on the Anachronism and Antiquity project funded by the Leverhulme Trust, with additional funding from the Faculty of Classics, Oxford. An earlier version was presented at the Celtic Classics Conference, Montreal. Further thanks are due to Malcolm Schofield who first persuaded me of the importance of this text. 